p-ISSN 1907-9850

e-ISSN 2599-2740

\title{
KANDUNGAN LOGAM BERAT TOTAL Pb DAN Cd DALAM SEDIMEN DAN BUAH PEDADA (Sonneratia alba) DI MUARA SUNGAI BADUNG
}

\author{
N. K. D. S. Widari*, I M. Siaka, I. E. Suprihatin \\ Program Studi Kimia, Fakultas Matematika dan Ilmu Pengetahuan Alam, Universitas Udayana \\ Jalan Kampus Unud-Jimbaran, Jimbaran-Bali, Indonesia \\ *e-mail: diah.pande@yahoo.co.id
}

\begin{abstract}
ABSTRAK
Penelitian ini telah dilakukan untuk menentukan kandungan logam berat $\mathrm{Pb}$ dan $\mathrm{Cd}$ total dalam sedimen dan buah pedada (Sonneratia alba) di Muara Sungai Badung yang dilakukan dengan metode digesti basah menggunakan pelarut reverse aqua regia. Logam berat diukur dengan menggunakan Spektrofotometer Serapan Atom (AAS) dan kuantitasi ke dua logam tersebut dilakukan dengan teknik kurva kalibrasi. Hasil penelitian menunjukkan bahwa konsentrasi logam $\mathrm{Pb}$ dan $\mathrm{Cd}$ total dalam sedimen berturut-turut 288,0131-376,0544 mg/kg dan 1,4849-7,0230 $\mathrm{mg} / \mathrm{kg}$, sedangkan dalam buah pedada berturut-turut $160,0212-245,4012 \mathrm{mg} / \mathrm{kg}$ dan 3,8151-14,6917 mg/kg. Hasil penelitian ini menunjukkan bahwa sedimen dan buah pedada dari Muara Sungai Badung ini telah tercemar oleh kedua logam tersebut karena kandungan logam $\mathrm{Pb}$ dan $\mathrm{Cd}$ baik dalam sedimen maupun buah pidada telah melebihi ambang batas yang diperbolehkan yaitu $\mathrm{Pb}$ dan $\mathrm{Cd}$ dalam sedimen, berturut-turut 35 dan $0,6 \mathrm{mg} / \mathrm{kg}$, sedangkan $\mathrm{Pb}$ dan Cd dalam buah, berturut-turut 0,5 dan $0,2 \mathrm{mg} / \mathrm{kg}$.
\end{abstract}

Kata kunci: Muara Sungai Badung, $\mathrm{Pb}$ dan $\mathrm{Cd}$, sedimen, Sonneratia alba

\begin{abstract}
This paper discusses the total contents of $\mathrm{Pb}$ and $\mathrm{Cd}$ metals in sediment and pedada fruit (Sonneratia alba) collected from Estuary of Badung River. Wet digestion method using reverse aqua regia was performed to extract the metals. All metals were measured using Atomic Absorption Spectrophotometer (AAS). The results showed that the total contents of $\mathrm{Pb}$ and $\mathrm{Cd}$ in the sediments were $288.0131-376.0544$ and $1.4849-7.0230 \mathrm{mg} / \mathrm{kg}$, respectively, while in the pedada fruit were 160.0212-245.4012 and 3.8151-14.6917 mg/kg, respectively. Based on the results, the content of Pd and $\mathrm{Cd}$ in the sediment and pedada fruit in the area of Badung River Estuary exceeded the limits allowed indicating that the sediment and the pidada fruts are polluted by $\mathrm{Pb}$ and $\mathrm{Cd}$ metals.
\end{abstract}

Keywords: Estuary of Badung River, $\mathrm{Pb}$ and $\mathrm{Cd}$, sediment, Sonneratia alba

\section{PENDAHULUAN}

Buah pedada (Sonneratia alba) adalah salah satu buah mangrove yang memiliki kandungan fitokimia seperti steroid, triterpenoid dan flavonoid (Ahmed dkk, 2010). Sonneratia alba memiliki beragam nama lokal yaitu pedada, prapat, bropak, bogem, pupat, prepat, peroppa, pangka, barapak, barropa, susup, mange-mange, kadada, muntu, sopo, dan brembang (Sarno,2013). Buah ini mengandung vitamin A, $\mathrm{B}_{1}, \mathrm{~B}_{2}$, dan $\mathrm{C}$ yang berperan dalam metabolisme tubuh, terutama produksi energi dan sintesis protein (Chen dkk., 2009; Nagelkerken dkk., 2008). Keunggulan dari buah ini yaitu sifat buahnya tidak beracun, dapat dimakan langsung, rasa asam dan aroma khas serta tekstur buah yang lembut membuat buah ini cocok diolah menjadi beberapa produk pangan seperti jenang, dodol, selai, dan sirup (Indra dkk., 2007).

Keberadaan buah ini sangat melimpah di Kawasan Taman Hutan Raya Ngurah Rai, seperti halnya di Muara Sungai Badung. Akan tetapi, tanaman mangrove merupakan tanaman penyerap berbagai zat termasuk polutan baik organik maupun anorganik yang terdapat di lingkungan sekitarnya. Oleh karena Muara sungai Badung merupakan tempat transit terakhir segala limbah buangan baik limbah domestik maupun industri, maka setiap cemaran 
termasuk logam berat dapat tertahan dalam interval waktu tertentu. Dengan demikian, tanaman mangrove yang tumbuh di kawasan tersebut berkesempatan menyerap segala cemaran tersebut. Akibatnya, cemaran anorganik seperti logam $\mathrm{Pb}$ dan $\mathrm{Cd}$ ikut diserap oleh tanaman mangrove dan logam tersebut dapat terakumulasi pada berbagai bagian tanaman, termasuk di bagian buahnya.

Wijayanti dkk. (2015) melaporkan bahwa sedimen sungai Badung mengandung logam berat $\mathrm{Pb}$ total sebesar 4,2669-27,9171 $\mathrm{mg} / \mathrm{kg}$ dan $\mathrm{Cu}$ total sebesar 20,5240-69,3782 $\mathrm{mg} / \mathrm{kg}$ sementara menurut Puspasari dkk (2014) sedimen di muara sungai tersebut sudah tercemar oleh logam Cu total sebesar 33,9036 mg/kg fakta ini diperkuat oleh Utari dkk. (2015) yang melaporkan bahwa buah pedada yang tumbuh di kawasan tersebut mengandung logam $\mathrm{Cu}$ sebesar $7,6497 \pm 0,5834 \mathrm{mg} / \mathrm{kg}$.

Logam berat dapat terserap ke dalam jaringan tanaman melalui akar yang selanjutnya akan masuk ke dalam siklus rantai makanan (Alloway, 1990). Dengan demikian, jika jaringan tanaman tersebut terkontaminasi, maka logam berat akan terakumulasi pada jaringan tubuh dan dapat menimbulkan keracunan bagi manusia, hewan, dan tumbuhan apabila melebihi ambang batas. (Gayatri dan Riza ,1994). Kandungan logam berat dalam tanaman maupun buah mangrove di Kawasan Muara Sungai Badung juga telah dilaporkan oleh beberapa peneliti seperti Suwandewi dkk. (2013), Sholihah dkk. (2014), Suprihatin dkk. (2014) dan Devi dkk. (2015).

Berdasarkan latar belakang diatas maka perlu dilakukan penelitian untuk memberikan informasi terbaru mengenai kondisi perairan muara Sungai Badung dilihat dari segi kandungan logam beratnya. Artikel ini melaporkan tentang kandungan logam $\mathrm{Pb}$ dan Cd total dalam sedimen dan buah pedada di Kawasan Muara Sungai Badung.

\section{BAHAN DAN METODE}

\section{Bahan dan Peralatan}

Bahan yang digunakan adalah $\mathrm{HNO}_{3}, \mathrm{HCl}$ dan aquades. Alat yang digunakan adalah ultrasonic bath, hotplate, ayakan $63 \mu \mathrm{m}$ peralatan gelas yang biasa digunakan dalam laboratorium dan AAS Merk Shimadzu Tipe A7000.

\section{Preparasi sampel}

Sampel yang telah kering dan diayak dengan ayakan $63 \mu \mathrm{m}$ ditimbang sebanyak 1 gram dan dimasukkan ke dalam gelas beaker. Selanjutnya ditambah $10 \mathrm{~mL}$ campuran $\mathrm{HNO}_{3}$ pekat dan $\mathrm{HCl}$ pekat (3:1) lalu ditutup dengan gelas arloji. Campuran tersebut didigesti dengan ultrasonic bath pada suhu $60^{\circ} \mathrm{C}$ selama 45 menit. Selanjutnya, campuran sampel dipanaskan pada hotplate pada suhu $140^{\circ} \mathrm{C}$ selama 45 menit. Campuran hasil pemanasan disaring dan filtratnya dimasukkan ke dalam labu ukur 100 $\mathrm{mL}$. Filtrat tersebut diencerkan dengan aquades hingga tanda batas (Siaka dkk. 2006). Selanjutnya absorbansi larutan sampel diukur dengan AAS.

\section{HASIL DAN PEMBAHASAN}

\section{Kandungan $\mathrm{Pb}$ dan $\mathrm{Cd}$ Total dalam Sedimen}

Kandungan logam $\mathrm{Pb}$ dan $\mathrm{Cd}$ total dalam sedimen di Kawasan Muara Sungai Badung terdeteksi di seluruh lokasi sampling, konsentrasi masing-masing logam ditentukan oleh persamaan regresi linier logam $\mathrm{Pb}$ yaitu $\mathrm{y}=$ $0,0339 x+0,0005$ dengan koefisien regresi $(R)$ sebesar 0,9990 dan untuk logam Cd adalah $\mathrm{y}=$ $0,207 x+0,024$ dengan koefisien regresi $(\mathrm{R})$ sebesar 0,9914. Dari kedua nilai regresi linier tersebut yaitu di atas 0,99 , terlihat adanya hubungan yang linear antara konsentrasi dan absorbansi masing-masing logam tersebut sehingga dapat digunakan untuk menghitung konsentrasi sampel

Pada Tabel 1 dapat dilihat bahwa kandungan logam $\mathrm{Pb}$ dan $\mathrm{Cd}$ total dalam sedimen memiliki konsentrasi yang tergolong tinggi dan ini melewati ambang batas yang diperbolehkan oleh Canadian Sediment Quality Guidelines (2001) yaitu $35 \mathrm{mg} / \mathrm{kg} \mathrm{Pb}$ dan 0,6 $\mathrm{mg} / \mathrm{kg} \mathrm{Cd}$. Kandungan logam $\mathrm{Pb}$ jauh lebih tinggi dibandingkan dengan logam $\mathrm{Cd}$, Hal ini dapat disebabkan karena sumber cemaran $\mathrm{Pb}$ di lingkungan tersebut lebih tinggi, serta terdapat aktivitas perahu di lingkungan muara yang menggunakan bahan bakar bensin. Tingginya 
kandungan logam berat dalam sedimen dapat digunakan sebagai cermin dalam meramalkan keberadaan logam berat dalam biota atau hayati yang ada di sekitar area tersebut.

Tabel 1. Kandungan Logam $\mathrm{Pb}$ dan $\mathrm{Cd}$ Total dalam Sedimen

\begin{tabular}{ccc}
\hline Lokasi & {$[\mathrm{Pb}] \mathrm{mg} / \mathrm{kg}$} & {$[\mathrm{Cd}] \mathrm{mg} / \mathrm{kg}$} \\
\hline 1 & $333,9989 \pm 0,1347$ & $4,6541 \pm 0,1709$ \\
2 & $369,3582 \pm 1,0634$ & $5,2171 \pm 0,0934$ \\
3 & $288,0131 \pm 1,6787$ & $1,4849 \pm 0,1125$ \\
4 & $376,0544 \pm 0,1210$ & $4,1472 \pm 0,0127$ \\
5 & $352,2394 \pm 0,9626$ & $7,0230 \pm 0,1495$ \\
\hline
\end{tabular}

\section{Kandungan Logam $\mathrm{Pb}$ dan $\mathrm{Cd}$ dalam Buah Pedada (Sonneratia alba)}

Tabel 2 menunjukkan bahwa buah pedada dari tanaman mangrove yang tumbuh di Kawasan Muara Sungai Badung mengandung logam $\mathrm{Pb}$ dengan konsentrasi yang sangat tinggi dalam setiap sampel yang diambil dari setiap lokasi, sementara kandungan logam $\mathrm{Cd}$ ditemukan dengan konsentrasi yang jauh lebih rendah daripada $\mathrm{Pb}$.

Lebih rendahnya kandungan logam $\mathrm{Cd}$ dibanding $\mathrm{Pb}$, dapat disebabkan karena kandungan $\mathrm{Cd}$ total dalam sedimen jauh lebih rendah disbanding $\mathrm{Pb}$. Ini dapat juga terjadi karena kandungan logam $\mathrm{Cd}$ yang berada di lingkungan tersebut telah terserap ke seluruh bagian pohon pedada lainnya seperti akar, batang dan daunnya.

Kandungan kedua logam tersebut dalam buah telah melewati ambang batas Standar Nasional Indonesia 7387 tahun 2009 yang menyatakan bahwa batas maksimum cemaran logam berat $\mathrm{Pb}$ dalam buah adalah $0,5 \mathrm{mg} / \mathrm{kg}$ dan $\mathrm{Cd}$ sebesar $0,2 \mathrm{mg} / \mathrm{kg}$. Hasil penelitian ini sejalan dengan penelitian sebelumnya (Suwandewi dkk., 2013; Puspasari dkk., 2014; Sholihah dkk., 2014; Suprihatin dkk., 2014; Utari dkk. 2015; dan Devi dkk., 2015). Menurut Rudiyanto (2016) buah Sonneratia alba memiliki waktu berbunga antara 3-4 bulan dan untuk pembuahan sampai masak membutuhkan waktu 2-3 bulan. Dalam kurun waktu tersebut akan terjadi penyerapan yang cukup lama sehingga akumulasi logam berat di dalam buah pedada tersebut semakin tinggi. Apabila buah tersebut dikonsumsi, maka dapat menimbulkan berbagai macam efek kesehatan bergantung pada jumlah kandungan logam berat di dalamnya, serta logam berat juga akan terakumulasi dalam tubuh dan dapat menimbulkan efek terhadap kesehatan pada jangka panjang.

Tabel 2. Kandungan Logam $\mathrm{Pb}$ dan $\mathrm{Cd}$ Total dalam Buah Pedada (Sonneratia alba)

\begin{tabular}{ccc}
\hline Lokasi & {$[\mathrm{Pb}] \mathrm{mg} / \mathrm{kg}$} & {$[\mathrm{Cd}] \mathrm{mg} / \mathrm{kg}$} \\
\hline 1 & $168,5649 \pm 2,2664$ & $13,4222 \pm 1,6526$ \\
2 & $245,4012 \pm 4,6819$ & $14,6917 \pm 0,9963$ \\
3 & $195,7795 \pm 4,9556$ & $3,8151 \pm 0,4769$ \\
4 & $160,0212 \pm 3,7323$ & $5,1058 \pm 1,3808$ \\
5 & $227,5859 \pm 5,6854$ & $8,7604 \pm 1,3835$ \\
\hline
\end{tabular}

\section{SIMPULAN DAN SARAN}

\section{Simpulan}

Kandungan logam $\mathrm{Pb}$ dan $\mathrm{Cd}$ total dalam sedimen berturut-turut sebesar 286,3344376,1754 dan $1,3724-7,1725 \mathrm{mg} / \mathrm{kg}$, serta dalam buah pedada sebesar 160,0212245,4012 dan 3,8151-14,6917 mg/kg. Hasil penelitian menunjukkan bahwa sedimen dan buah pedada di Kawasan Muara Sungai Badung telah tercemar logam $\mathrm{Pb}$ dan $\mathrm{Cd}$, serta tidak direkomendasikan untuk menggunakan buah pedada (Sonneratia alba) sebagai bahan olahan pangan.

\section{UCAPAN TERIMA KASIH}

Penulis mengucapkan terimakasih kepada staff wisata kano dan mangrove atas fasilitas dan bantuannya selama proses sampling. Terimakasih juga kepada kepala dan staff Lab. Bersama FMIPA Universitas Udayana atas fasilitas laboratorium yang diberikan, serta seluruh pihak yang telah membantu menyelesaikan penelitian ini.

\section{DAFTAR PUSTAKA}

Ahmed R., Moushumi, S.J., Ahmed, H., Ali, M., Haq, W.M., Jahan, R. and Rahmatullah, M., 2010, Serum glucose and lipid 
profiles in rats following administration of Sonneratia caseolaris (L.) Engl. (Sonneratiaceae) leaf powder in diet, Advances in Natural and Applied Sciences, 4(2): 171173

Alloway, B.J., 1990, Heavy Metal in Soils. Jhon Willey and Sons Inc., New York

Badan Standardisasi Nasional, 2009, Batas Maksimum Cemaran Logam Berat Dalam Pangan, SNI-7387:2009, Jakarta

Canadian Countil of Ministers of the Environment No. 1299 2001, Canadian Sediment Quality Guidelines for the Protection of Aquatic Life, ISBN 1896997-34-1

Chen, L., Zan, Q., Mingguang, L., Shen, J., Liao, W., 2009, Litter dynamics and forest structure of the introduced Sonneratia caseolaris mangrove forest in Shenzhen, China, Estuarine, Coastal and Shelf Science, 85:241 -246

Gayatri dan Riza, V.T., 1994, Bunga Rampai Residu Pestisida dan Alternatifnya, PAN Indonesia, Jakarta

Indra R., Nofita, Y. dan Wahyu, A., 2007, Identifikasi Ekosistem Mangrove di Surabaya, Penelitian, Universitas Airlangga, Surabaya

Nagelkerken, I., Blaber S.J.M., Bouillon, S., Green, P., Haywood, M., and Kirton, L.G., 2008, The habitat of mangroves for terrestrial and marine fauna: a review, Aquatic Botany, 89: 155-185

Puspasari, D.A., Suprihatin, I.E., Panca Dewi, I.G.A.K.S., 2014, Spesiasi dan Bioavailabilitas Logam $\mathrm{Cu}$ dan $\mathrm{Zn}$ dalam Perairan dan Sedimen Muara Sungai Badung pada Jalur Taman Hutan Raya Ngurah Rai Denpasar Bali, Jurnal Kimia, 8(2): 153-158

Rudiyanto, Arif, 2016, Bogem: Apel MangroveSonneratia Alba, Biodiversity Warriors by Kehati, 30 April 2016

Sarno, 2013, Petunjuk Teknis: Pemanfaatan Buah Mangrove Sebagai Bahan Makanan, CoE Place Unsri, Universitas Sriwijaya, Palembang
Sholihah, I.H., Suprihatin, I.E., Laksmiwati, A.A.I.A.M., 2014, Distribusi Timbal $(\mathrm{Pb})$ dan Kadmium (Cd) pada Buah Tanaman Mangrove Rhizophora mucronate di Muara Sungai Mati Kabupaten Badung, Cakra Kimia, 2(2): 32-36

Siaka, M., Owens, C.M. and Birch, G.F., 2006, Evaluation of Some Digestion Methods for the Determination of Heavy Metals in Sediment Sample by Flame-AAS, Analytical Letters, 31(4): 703-718

Suprihatin, I.E., Manurung, M., dan Devi, M., 2014, Logam Kromium (Cr) dan Seng (Zn) dalam Akar, Batang, dan Daun Tumbuhan Mangrove Rhizophora apiculate Di Muara Sungai Badung, Jurnal Kimia, 8 (2): 178-182

Suwandewi, A.A.S.A., I.E. Suprihatin, M. Manurung, 2013, Akumulasi Logam Kromium (Cr) dalam Sedimen, Akar dan Daun Mangrove Avicennia marina di Muara Sungai Badung, Jurnal Kimia, 7(2): 181-185

Utari, A.A.P.C.P.U., Suprihatin, I.E., dan Ariati, N.K., 2015, Kandungan Tembaga $(\mathrm{Cu})$ Buah Lindur (Bruguiera gymnorrhiza), Pedada (Sonneratia caseolaris), Nyirih (Xylocarpus granatum), Dan Bakau (Rhizophora mucronate) Di Taman Hutan Raya Ngurah Rai Bali, Jurnal Kimia, 4 (1): 49-54

Wijayanti, Nanik, I.M Siaka, I.A.G Widihati, 2015, Spesiasi Dan Bioavailabilitas Logam Berat Timbal (Pb) Dan Tembaga (Cu) Dalam Sedimen Sungai Tukad Badung, Jurnal Kimia, 9(2): 211-2 